\title{
PROFILE OF FATTY ACIDS AND SPECTROSCOPIC CHARACTERISTICS OF SELECTED VEGETABLE OILS EXTRACTED BY COLD MACERATION
}

\author{
Magdalena Kachel $^{\mathrm{a}^{*}}$, Arkadiusz Matwijczuk ${ }^{\mathrm{b}}$, Artur Przywara ${ }^{\mathrm{a}}$, Artur Kraszkiewicz ${ }^{\mathrm{a}}$, \\ Milan Koszel $^{\mathrm{a}}$ \\ ${ }^{a}$ Department of Machines Usage and Management of Production Processes, University of Life \\ Sciences, Lublin \\ ${ }^{\mathrm{b}}$ Department of Physics, University of Life Sciences, Lublin \\ ${ }^{*}$ Corresponding author: e-mail: magdalena.kachel@up.lublin.pl

\begin{tabular}{l}
\hline ARTICLE INFO \\
\hline Article history: \\
Received: September 2017 \\
Received in the revised form: \\
October 2017 \\
Accepted: November 2017 \\
\hline Key words: \\
pumpkin seeds, \\
rapeseeds, \\
cold pressed oils, \\
fatty acids, \\
ATR-FTIR \\
\hline
\end{tabular}

\begin{abstract}
Biodiesel has become more attractive material for its properties such as biodegradability, renewability and very low toxicity of its combustion products. A higher quality of this fuel is essential in its potential commercialization. Analytical methods used in biodiesel analysis are constantly refined. The most popular analytical techniques include chromatography and molecular spectroscopy. The ATR-FTIR spectroscopy is one of the most important methods of spectroscopy. This paper presents the results of studies on selected oils of natural origin using ATR-FTIR infrared absorption spectroscopy. Three types of oils from pumpkin seeds and winter rapeseed were analysed. The main
\end{abstract} \\ fatty acids were also determined in all the samples.
}

\section{Introduction}

Within the recent decade much attention was paid to the concept of sustainable economic systems including valorization of local biomass. Plant by products are cheap and include many compounds, such as: lignocellulosis, raw material for obtaining polysaccharides, proteins, fats with wide spectrum of polyunsaturated fatty acids n-3 and n-6 or steroles which indicate bioactive activity (Parry et al., 2008; Tuberoso et al., 2007). Plants which are particularly rich in the above mentioned chemical compounds include oily plants such as rapeseed (Brassica napus L.) and pumpkin (Cucurbita moschata), which are cultivated both in Europe and around the world. These plants are mainly cultivated for fodder and food. However, recently their use has been appreciated as a bio-product source for production of for example biodiesel and biodegradable smears (Schinas et al. 2009; Koutsouki et al. 2016; Verma and Sharma, 2016). Customers are increasingly interested in cold pressed oils also due to the manner of their obtaining. In case of cold pressing, the use of high temperature is not taken into consideration and its possible growth during cold pressing takes place as a result of natural friction of cooperating elements of devices (press). The oil and plant fat pressing procedure does not allow for chemical substances to be used for oil puri- 
fication by increasing retention of phytochemical compounds to oil (Parry et al. 2006; Latif et al. 2007; Soto et al. 2008).

A high quality of cold pressed oils depends on several factors. Firstly, on the quality of raw material including such properties as: purity, uniformity, no damages, or relevant maturity of raw material (Obiedzińska and Waszkiewicz-Robak, 2012). Usefulness of oil both for food and biofuel depends mainly on the fatty acids profile in seeds. In case of biofuels, oils with high content of polyunsaturated fatty acids reduce the efficiency of fuel production process (Myczko and Golimowska, 2011). It concerns linolic and linoleic acids which respectively have two and three double connections in the carbon chain. Fatty acids composition influences such biofuel properties as cetane number, rheological properties, low temperature properties i.e. cloud-point, cold filter plugging point and clotting time (Canakci and Sandli, 2008).

Obtained edible oils from the above mentioned pumpkin and rapeseed are one of the most important groups of products rich in food components. Composition of fatty acids and the number of bioactive components in rapeseed oil ensures a high nutritive value. Rapeseed oil includes small amounts of saturated fatty acids $(<7 \%)$, considerably big amounts of polyunsaturated acids as linoleic acid (n-6) and $\alpha$-linolenic and monounsaturated acids, in particular: oleinic which constitutes from 61.6\% (Obiedzińska and Waszkiewicz-Robak, 2012). Fatty acids that belong to $n-5$ group prevent, inter alia, the circulatory system diseases as well as artherosclerosis and play an important role in prevention and treatment of chronic illnesses such as heart diseases, neurodegenerative diseases, tumors and rheumatoid arthritis and even may reduce mental illnesses incidence (Kapoor and Huang, 2006). Their activity is related to ability of active compounds to destroy free radicals which are responsible for oxidization damage to lipids, proteins and nucleic acids (Eder and Brandsch, 2002; Bouzid et al., 2005; Kim et al., 2006).

Pumpkin seeds have a high content of protein within 73-86\% (Mansour et al. 1993) and fat content of up to $45 \%$ (Kolayli et al., 2011). The obtained oil is dark green and have a high content of unsaturated fatty acids which is even $78 \%$ (Younis et al., 2000; El-Adawy and Taha, 2001). a Special composition of acids is ad advantage of oil pressed from pumpkin. Fatty acids in oil include: palmitic acid (C16:0, 9.5-14.5\% water content), stearic acid (C18:0, 3.1-7.4\%), linoleic acid (C18:2, 35.6-60.8\%) and oleinic acid (C18:1, 21.0-46.9\%) (Lazos et al., 1995; Murkovic and Pfannhauser, 2000; El-Adawy and Taha, 2001; Parker et al., 2003; Ramadan and Mörsel, 2003; Parry and Yu, 2004).

Application of a fast and reliable method of the quantity determination of the fat content is one of the key tasks in the quality control. The fat content in oils may be monitored with ATR-FTIR infrared spectometry (Kowalski,, 1995), the aim of which is mainly to exclude unfavourable changes in the product and to enable the producer to quickly intervene in the production process during its course (Van de Voort, 1992). The ATR-FTIR method enables investigation of solid bodies, liquids and pastes giving the same repeatable results (Kuehl and Crocombe, 1984). Spectroscopy techniques have great potential. Infrared spectroscopy may be used both for determination of chemical properties of fats (numbers: iodine, sponification, acid, peroxide value) as well as to trace processing chemical changes e.g. autooxidization (Van de Voort, 1992; Van de Voort et al., 2001).

The objective of the paper was to analyse fatty acids profile in shellless pumpkin seeds and winter rapeseed of selected cultivars and characteristics of cold pressed oils with the FTIR spectroscopy method. 
Profile of fatty acids...

\section{Materials and methods}

\section{Material}

Research material consisted of winter rape seeds of Abakus, Bellevue and Adriana mixed cultivars and shellless pumpkin seeds of the following cultivars: 'Olga', 'Miranda' and' Junona' 2 kilo each. All plants were cultivated in south-east Poland on the territory of Lubelskie Voivodeship in the year of harvesting 2014. Seeds after harvesting were dried in natural conditions in the temperature of $20^{\circ} \mathrm{C}$ in the surrounding of $60-70 \%$ of moisture in thin layers which do not exceed $1 \mathrm{~cm}$.

\section{Methods}

Fatty acids profile was determined in rape and pumpkin seeds according to PN-EN ISO 5509:2001: Oils, plant and animal fats - Analysis of methyl esters of fatty acids with the gas chromatography method in the central Agroecological Laboratory of the University of Life Sciences in Lublin.

Oil from rape and pumpkin seeds was pressed with the use of a screw press with a replaceable nozzle with a diameter of $8 \mathrm{~mm}$ along with the set of sieves by Farmet DUO company with continuous operation and performance up to $35 \mathrm{~kg} \cdot \mathrm{h}^{-1}$. Before starting the press was heated to $60^{\circ} \mathrm{C}$. After the temperature was stabilized, the pressing process has been initiated, stabilization of which was achieved after oil was pressed from the mass of approximately 1 kilo of seeds. Then, the temperature of the oil outlet screw cup was $70^{\circ} \mathrm{C}$. Pressing temperature was measured with a digital thermometer AD $20 \mathrm{TH}$ ama-digit. Oil after pressing was placed in dark glass bottles and left in the temperature of $5^{\circ} \mathrm{C}$ in order to naturally separate oil from the sediment for 6 days. Then, clean oil was poured to new bottles with the volume of $200 \mathrm{~cm}^{3}$ and subjected to analyses.

The obtained results of the composition profiles of fatty acids were subjected to statistical analysis with the use of a single factor analysis of variance with the use of Statistica 10.0 program. Significance of differences between averages was determined with the use of Tukey's test at the level of significance of $p<0.05$.

FTIR measurements were made with the use of spectrometer 670 - IR Varian with Fourier FTIR transformation. An optic system included Michelson type interferometer, measuring chamber (during measurements filled with argon). Attenuated Total Reflection attachment was used in the form of $\mathrm{ZnSe}$ monocrystal with relevant geometry (shear angle $45^{\circ}$ ), which ensures 10 times internal reflection of the absorbed band. The measurement chamber was dried with dry air for $1 \mathrm{~h}$ before tests were started. Spectra were measured in the area from 400 to $4000 \mathrm{~cm}^{-1}$ with resolution of $2 \mathrm{~cm}^{-1}$.

\section{Results and discussion}

Fatty acids profile of all samples (Table 1) corresponded to data included in Codex Alimentarius (2011). Based on the obtained results it was stated that pumpkin seeds have a considerably higher content of SFA acids, PUFA and Omega 6 than rape seeds. SFA percentage content in pumpkin seeds fluctuated from $18.71 \%$ for Junona cultivar to $18.80 \%$ for Olga cultivar. 
M. Kachel, A. Matwijczuk, A. Przywara, A. Kraszkiewicz, M. Koszel

Table 1.

Fatty acids composition for selected varieties of winter rape and pumpkin seeds

\begin{tabular}{|c|c|c|c|c|c|c|}
\hline \multirow{2}{*}{ Specification } & \multicolumn{3}{|c|}{ Pumkin seeds } & \multicolumn{3}{|c|}{ Rapeseeds } \\
\hline & 'Olga' & 'Junona' & 'Miranda' & 'Abakus' & 'Bellevue' & 'Adriana' \\
\hline C6:0 & 0.05 & 0.05 & 0.05 & 0.05 & 0.05 & 0.05 \\
\hline $\mathrm{C} 8: 0$ & 0.05 & 0.05 & 0.05 & 0.05 & 0.05 & 0.05 \\
\hline C10:0 & 0.05 & 0.05 & 0.05 & 0.05 & 0.05 & 0.05 \\
\hline C11:0 & 0.05 & 0.05 & 0.05 & 0.05 & 0.05 & 0.05 \\
\hline $\mathrm{C} 12: 0$ & 0.05 & 0.05 & 0.05 & 0.05 & 0.05 & 0.05 \\
\hline C13:0 & 0.05 & 0.05 & 0.05 & 0.05 & 0.05 & 0.05 \\
\hline $\mathrm{C} 14: 0$ & $0.11 \pm 0.01$ & $0.11 \pm 0.01$ & $0.10 \pm 0.01$ & $0.07 \pm 0.02$ & $0.09 \pm 0.02$ & $0.09 \pm 0.02$ \\
\hline C15:0 & 0.05 & 0.05 & 0.05 & 0.05 & 0.05 & 0.05 \\
\hline C15:1 & 0.05 & 0.05 & 0.05 & 0.05 & 0.05 & 0.05 \\
\hline C16:0 & $12.77 \pm 0.35$ & $12.18 \pm 0.34$ & $13.06 \pm 0.36$ & $5.37 \pm 0.07$ & $5.22 \pm 0.72$ & $5.33 \pm 0.68$ \\
\hline C16:1 & $0.13 \pm 0$ & 0.08 & 0.1 & $0.32 \pm 0.02$ & 0.31 & 0.30 \\
\hline C17:0 & $0.07 \pm 0.01$ & $0.07 \pm 0.01$ & $0.06 \pm 0.01$ & $0.06 \pm 0.01$ & 0.05 & 0.05 \\
\hline C17:1 & 0.05 & 0.05 & 0.05 & $0.09 \pm 0.01$ & 0.08 & 0.08 \\
\hline C18:0 & $5.24 \pm 0.20$ & $5.18 \pm 0.20$ & $4.58 \pm 0.18$ & $1.59 \pm 0.18$ & $1.71 \pm 0.18$ & $2.04 \pm 0.21$ \\
\hline $\mathrm{C} 18: \ln 9 \mathrm{c}+\mathrm{C} 18: \ln 9 \mathrm{t}$ & $18.89 \pm 0.97$ & $15.07 \pm 0.77$ & $17.93 \pm 0.92$ & $66.28 \pm 0.62$ & $62.41 \pm 0.33$ & $65.76 \pm 0.87$ \\
\hline $\mathrm{C} 18: 2 \mathrm{n} 6 \mathrm{c}+\mathrm{C} 18 \mathrm{2} 2 \mathrm{n} 6 \mathrm{t}$ & $61.65 \pm 1.63$ & $66.19 \pm 1.75$ & $63.10 \pm 1.66$ & $24.59 \pm 1.60$ & $20.48 \pm 0.27$ & $17.99 \pm 0.51$ \\
\hline C18:3n6 (gamma) & 0.05 & 0.05 & 0.05 & 0.05 & 0.05 & 0.05 \\
\hline C18:3n3 (alpha) & 0.36 & $0.31 \pm 0$ & $0.28 \pm 0$ & $0.07 \pm 0.01$ & $6.90 \pm 0.20$ & $6.22 \pm 0.18$ \\
\hline C20:0 & 0.37 & $0.37 \pm 0$ & $0.35 \pm 0$ & $0.54 \pm 0.06$ & $0.63 \pm 0.06$ & $0.69 \pm 0.06$ \\
\hline $\mathrm{C} 20: 1$ & $0.09 \pm 0$ & $0.09 \pm 0$ & $0.10 \pm 0$ & 0.05 & $1.66 \pm 0.25$ & $1.38 \pm 0.21$ \\
\hline $\mathrm{C} 20: 2$ & 0.05 & 0.05 & 0.05 & 0.05 & 0.08 & 0.06 \\
\hline $\mathrm{C} 20: 3 \mathrm{n} 6$ & 0.05 & 0.05 & 0.05 & 0.05 & 0.05 & 0.05 \\
\hline $\mathrm{C} 21: 0$ & 0.05 & 0.05 & 0.05 & 0.05 & 0.05 & 0.05 \\
\hline C20:3n3 & 0.05 & 0.05 & 0.05 & 0.05 & 0.05 & 0.05 \\
\hline C20:4 & 0.05 & 0.05 & 0.05 & 0.05 & 0.05 & 0.05 \\
\hline C20:5 & 0.05 & 0.05 & 0.05 & $0.3 \pm 0.04$ & 0.05 & 0.05 \\
\hline $\mathrm{C} 22: 0$ & $0.18 \pm 0$ & $0.19 \pm 0$ & $0.19 \pm 0$ & 0.05 & $0.37 \pm 0.03$ & $0.36 \pm 0.03$ \\
\hline $\mathrm{C} 22: \ln 9$ & 0.05 & 0.05 & 0.05 & 0.05 & $0.08 \pm 0.01$ & 0.05 \\
\hline $\mathrm{C} 22: 2$ & 0.05 & 0.05 & 0.05 & $0.66 \pm 0.02$ & 0.05 & 0.05 \\
\hline CC23:0 & 0.05 & 0.05 & 0.05 & 0.05 & 0.05 & 0.05 \\
\hline $\mathrm{C} 24: 0$ & 0.05 & 0.05 & 0.05 & 0.05 & $0.19 \pm 0.03$ & $0.17 \pm 0.03$ \\
\hline $\mathrm{C} 24: 1$ & $0.07 \pm 0$ & $0.07 \pm 0$ & $0.08 \pm 0$ & 0.05 & 0.19 & 0.14 \\
\hline SFA & 18.8 & 18.17 & 18.41 & 7.62 & 7.76 & 7.99 \\
\hline MUFA & $19.11 \mathrm{a}$ & $15.24 \mathrm{~b}$ & $18.13 \mathrm{a}$ & $66.68 \mathrm{c}$ & $64.71 \mathrm{~d}$ & $67.66 \mathrm{c}$ \\
\hline PUFA & $62.01 \mathrm{a}$ & $66.5 b$ & $63.38 \mathrm{c}$ & $25.61 d$ & $27.53 \mathrm{e}$ & $24.27 \mathrm{~d}$ \\
\hline OMEGA 3 & $0.36 \mathrm{a}$ & $0.31 \mathrm{a}$ & $0.28 b$ & $0.37 \mathrm{a}$ & $6.90 \mathrm{c}$ & $6.22 \mathrm{c}$ \\
\hline OMEGA 6 & $61.65 \mathrm{a}$ & $66.19 b$ & $63.10 \mathrm{c}$ & $24.59 \mathrm{~d}$ & $20.48 \mathrm{e}$ & $17.99 \mathrm{f}$ \\
\hline
\end{tabular}

For rape seeds this value was from 7.62 for Abakus cultivar to $7.99 \%$ for Adriana cultivar. Winter rape seeds had a higher content of monounsaturated acids. Their content was witin $64.71 \%$ for Bellevue cultivar to $67.66 \%$ for Adriana cultivar. The amount of the above mentioned acids in pumpkin seeds was considerably lower and it was from $15.24 \%$ for Junona cultivar to $19.11 \%$ for Olga cultivar. Omega 6 percentage share in pumpkin 
Profile of fatty acids...

seeds was $61.65 \%$ for Olga cultivar and as much as $66.19 \%$ for Junona cultivar. Omega 3 acids occurred in pumpkin seeds and in one cultivar of seeds (Anbakus) in a similar amount (from $0.28 \%$ for Mirinda pumpkin to $0.37 \%$ for Abakus rapeseed). The remaining two cultivars of winter rapeseed had higher content of Omega 3 acids which was 6.90 for Bellevue cultivar and $6.22 \%$ for Adriana cultivar.

Participation of main fatty acids in all analysed samples of pumpkin seeds was as follows: acid C18:2n6c (61.65-66.19\%), acid C18:1n9c (15.07-18.89\%) and acid $\mathrm{C} 16: 0$ (12.18-13.06\%), and in case of winter rape seeds: $\mathrm{C} 18: 1 \mathrm{n} 9 \mathrm{c}$ (62.41-66.28\%), acid C18:2n6c $(17.99-24.59 \%)$ and $\mathrm{C} 16: 0(5.22-5.37 \%)$. The obtained composition of acids in seeds was comparable to results published by other authors (Dubois et al. 2007; Sabudak 2007).

Statistical analysis with the use of post - hoc Tukey's test at the level of significance $\mathrm{p}<0.05$ confirmed statistical differences in the content of SFA, MUFA, PUFA and Omega 3 acids and Omega 6 acids between pumpkin and winter rape seeds. Statistical differences were also observed between Abakus, Belleuve and Adriana rape seeds.

\section{ATR-FTIR spectroscopy analysis}

Figure 1 presents ATR-FTIR spectra of the investigated samples of pumpkin oils (Panel A) and oils obtained from rape (Panel B). Samples were placed on the SNSe crystal and investigated in $\mathrm{N}_{2}$ atmosphere. Infrared spectra (ATR-FTIR) of the oil samples selected for research have quite intensive bands which may be attributed to specific functional groups of both food components and materials characteristic for biodiesel production. Edible fats, plant and animal oils and some substance for biodiesel production consist basically of trigliceride groups with a varied compostion of relevant fractions whose main differences consist in the degree and form of unsaturation of acyl groups as well as their length (Guillen and Cabo, 1997). Although some authors in their published papers made suitable attributions to specific bands in oil or fat spectra (Guillen and Cabo, 1997; Mehrotra, 2000; Vlachos et al., 2006; Guillen and Cabo, 1997; Radović et al., 2013) in specific vibrations or their groups. Although many authors referred the origin of vibrations characteristic for specific functional groups or their connections, it is difficult to attribute some bands for vibrations of the relevant functional group. Table 2 presents in detail frequency of spectra characteristic for their extensions (arms) in spectra of 6 pumpkin oil samples of the following cultivars: Olga, Junona and Mirinda and rapeseed cultivars: Abakus, Bellevue and Adriana as well as their allotment to relevant functional groups. With the use of relevant bottom indices their intensity in typical spectra in the infrared region was also presented. It should be emphasised that ascribing spectra corresponding to valence vibrations in FTIR is usually easier than alloting bands corresponding to bending vibrations as a result of frequent concurrence of this type of vibrations. Thus, in the presented absorption spectra of the oil samples selected for investigations one may notice methyl group vibrations which are between 1350 and $1150 \mathrm{~cm}^{-1}$. These are valence vibrations from C-H group vibrations in groups $-\mathrm{CH}_{3}\left(\sim 1350-60 \mathrm{~cm}^{-1}\right)$ and bending vibrations in this group $\left(\sim 1160 \mathrm{~cm}^{-1}\right)$. On the other hand, valence vibrations of the ester bonds $\mathrm{C}-\mathrm{O}$ consist of two combined assymetrical vibrations $\mathrm{C}-\mathrm{C}(=\mathrm{O})-\mathrm{O}$ and $\mathrm{O}-\mathrm{C}-\mathrm{C}$, but the first one is considerably more important and intensive (Yang et al., 2005; Safar et al., 1994). These bands occur in the region between 1300 (some $\mathrm{C}-\mathrm{C}(=\mathrm{O})-\mathrm{O}$ in our case approximately $1280 \mathrm{~cm}^{-1}$ ) and $1000 \mathrm{~cm}^{-1}$ (approximately $1030 \mathrm{~cm}^{-1}$ for this combination of groups). Saturated esters bands $\mathrm{C}-\mathrm{C}(=\mathrm{O})-\mathrm{O}$ occur 
between 1230 and $1160 \mathrm{~cm}^{-1}$ and in case of unsaturated esters vibrations occur usually at lower frequencies. On the other hand, O-C-O bands from primary alcohol occur in the range between 1090 and $1020 \mathrm{~cm}^{-1}$ while in case of secondary alcohols this band occurs approximately at $1100 \mathrm{~cm}-1$ (in our case approximately 1097-1100).

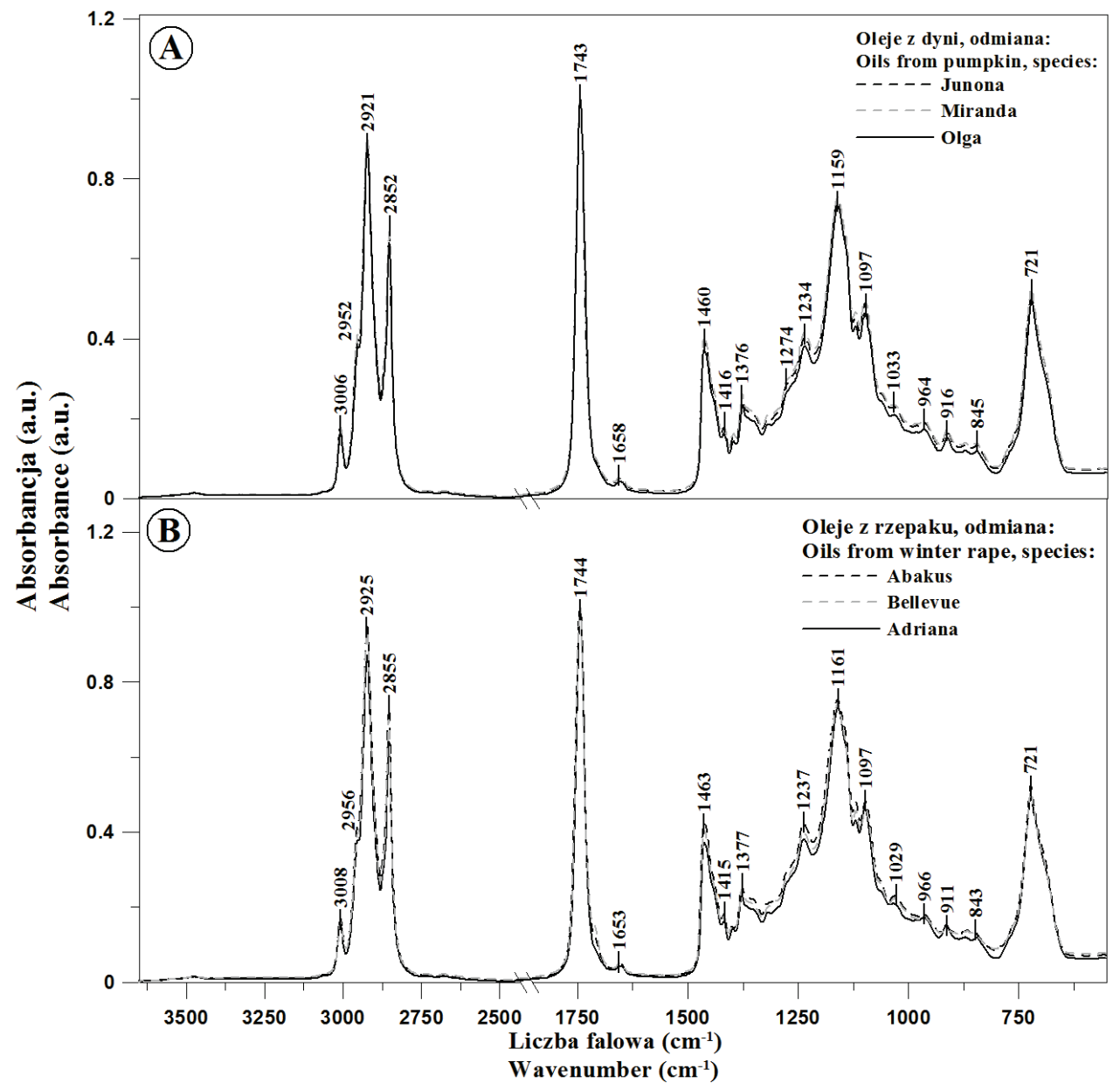

Figure 1. ATR-FTIR spectra for selected samples of oil from pumpkin ('Junona', 'Miranda' and 'Olga', Panel A) and from winter rape ('Abakus', 'Bellevue' and 'Adriana', Panel B)

Both types of esters are present in triglyceride particles. However, some authors attribute the band at approximately $1239-4 \mathrm{~cm}^{-1}$ only to bending vibrations of the methyl group outside the plane (Gurdeniz and Ozen 2009; Ahmad et al. 2014). Two bands presented in Table 2 (and in fig. 1) may cause slight trouble in their suitable attribution: one of the maximum approximately $1415 \mathrm{~cm}^{-1}$ and the second of the maximum approximately 
Profile of fatty acids...

$1320 \mathrm{~cm}^{-1}$ (in this case extension of the band is considered, Fig.1). The first group of vibrations with the maximum of $1415 \mathrm{~cm}^{-1}$ (fig. 1) may be allotted to methyl group vibrations in the aliphatic chains of tested oils (Gurdeniz and Ozen 2009). The second and (more specifically extension) with the maximum of approximately $1320 \mathrm{~cm}^{-1}$ is reported in all samples where at the same time bands with the maximum of $966 / 4$ and $916 / 1 \mathrm{~cm}^{-1}$ are observed. It should be noticed that the band of approximately $916 / 1 \mathrm{~cm}^{-1}$ (depending whether these are oil samples from pumpkin or rape), which appears in all oil samples is related to valence vibrations cis - substituted olefinic groups (Guillen and Cabo 1997; Rohman et al. 2014) as well as it may come from vinyl groups vibrations.

Table 2.

The position of maxima absorption bands with the appropriate vibration in spectral range from 3800 to $550 \mathrm{~cm}^{-1}$ for selected varieties of rape and pumpkin seeds (samples oils of pumpkin seeds: Olga, Junona, Miranda and samples oils of rapeseeds: Abakus, Bellevue and Adriana, respectively)

\begin{tabular}{|c|c|c|c|c|c|c|}
\hline \multicolumn{6}{|c|}{$\begin{array}{c}\text { ATR-FTIR } \\
\text { Position of bands }\left(\mathrm{cm}^{-1}\right) \\
\end{array}$} & \multirow{3}{*}{$\begin{array}{l}\text { Type and origin of } \\
\text { vibrations }\end{array}$} \\
\hline \multicolumn{3}{|c|}{ Oils of pumpkin seeds } & \multicolumn{3}{|c|}{ Oils of rapeseeds } & \\
\hline 'Olga' & 'Junona' & 'Miranda' & 'Abakus' & 'Bellevue' & 'Adriana' & \\
\hline 3010 & 3010 & 3005 & 3006 & 3006 & 3005 & $v\left(=\mathrm{C}-\mathrm{H}_{\mathrm{vw}}\right.$, trans -$)$ \\
\hline 2955 & 2957 & 2955 & 2951 & 2949 & 2952 & $v_{\mathrm{as}}\left(-\mathrm{C}-\mathrm{H}_{\mathrm{m}},-\mathrm{CH}_{3}\right)$ \\
\hline 2925 & 2921 & 2923 & 2922 & 2924 & 2920 & $\begin{array}{c}v_{\mathrm{as}}\left(-\mathrm{C}-\mathrm{H}_{\mathrm{vst}},-\mathrm{CH}_{\mathrm{a}}\right) \\
\text { and }\end{array}$ \\
\hline 2852 & 2853 & 2852 & 2852 & 2851 & 2851 & $\begin{array}{l}v_{\mathrm{s}}\left(-\mathrm{C}-\mathrm{H}_{\mathrm{vst}},-\mathrm{CH}_{\mathrm{a}}\right) \\
\text { (aliphatic group of } \\
\text { triglycerides) }\end{array}$ \\
\hline 1744 & 1744 & 1744 & 1743 & 1743 & 1745 & $\mathrm{C}=\mathrm{O}$ in ester \\
\hline 1709 & 1709 & 1709 & 1709 & 1709 & 1709 & $v\left(-\mathrm{C}=\mathrm{O}_{\mathrm{vw}}\right)$ in acid \\
\hline 1658 & 1654 & 1655 & 1653 & 1656 & 1652 & $v_{\mathrm{vw}}(-\mathrm{C}=\mathrm{C}-$, cis- $)$ \\
\hline 1464 & 1462 & 1461 & 1460 & 1461 & 1463 & $\begin{array}{l}v_{\mathrm{vw}}(-\mathrm{C}-\mathrm{H}, \text { cis-) bend- } \\
\text { ing (rocking) }\end{array}$ \\
\hline 1419 & 1419 & 1415 & 1417 & 1415 & 1415 & $\left(-\mathrm{C}-\mathrm{H},-\mathrm{CH}_{3}\right)$ \\
\hline 1375 & 1379 & 1379 & 1377 & 1377 & 1375 & $\begin{array}{l}\mathrm{w}, \mathrm{m}, \mathrm{vw}\left(-\mathrm{C}-\mathrm{H},-\mathrm{CH}_{3}\right), \\
\text { banding }\end{array}$ \\
\hline 1357 & 1353 & 1357 & 1351 & 1359 & 1358 & \\
\hline 1275 & 1276 & 1276 & 1277 & 1274 & 1280 & \\
\hline 1235 & 1239 & 1238 & 1237 & 1237 & 1234 & $v_{\mathrm{m}}(-\mathrm{C}-\mathrm{O})$ or $\mathrm{d}_{\mathrm{m}}\left(-\mathrm{CH}_{2^{-}}\right)$ \\
\hline 1159 & 1162 & 1164 & 1161 & 1161 & 1160 & $v_{\mathrm{st}}(-\mathrm{C}-\mathrm{O})$ or $\delta_{\mathrm{st}}\left(-\mathrm{CH}_{2}-\right)$ \\
\hline 1097 & 1099 & 1097 & 1099 & 1096 & 1095 & \\
\hline 1036 & 1036 & 1035 & 1025 & 1030 & 1029 & $v_{\mathrm{m}, \mathrm{vw}}(-\mathrm{C}-\mathrm{O})$ \\
\hline 965 & 967 & 965 & 962 & 965 & 962 & $\delta_{\mathrm{w}}(-\mathrm{HC}=\mathrm{CH}-$, trans -$)$ \\
\hline 915 & 919 & 914 & 912 & 913 & 911 & bending out of plane \\
\hline 872 & 869 & 872 & 866 & 869 & 866 & \\
\hline 847 & 845 & 844 & 845 & 847 & 847 & $\delta\left(-\left(\mathrm{CH}_{2}\right)_{\mathrm{n}}-\right.$ and - \\
\hline 724 & 719 & 721 & 722 & 723 & 720 & $\begin{aligned} \mathrm{HC}=\mathrm{CH}-(\text { cis-) bend- } \\
\text { ing (rocking) }\end{aligned}$ \\
\hline
\end{tabular}

w - weak 
Although, the investigated oil bands seem to be similar there are considerable differences in the intensity of relevant bands as well as in their precise frequency where we observe their maximum absorbance. It is clearly related to a different nature and composition of the investigated oil sample. However, it should be emphasised that in order to interpret the spectra easily as well as to better present them, all spectra were normalized in the maximum bands which correspond to vibrations of the carbonyl group $\mathrm{C}=\mathrm{O}\left(1743 / 4 \mathrm{~cm}^{-1}\right)$. Bands with the maximum at approximately $1744 / 3 \mathrm{~cm}^{-1}$ are characteristic for vibrations of the carbonyl group $\mathrm{C}=\mathrm{O}$ (Koczoń et al., 2016) in esters. On the other hand, a very weak band with the maximum of approximately $1709 \mathrm{~cm}^{-1}$ constitutes weak vibrations of the carbonyl group which occur in acid groups. Subsequent bands with the maximum of approximately $1658 / 3 \mathrm{~cm}^{-1}$ are vibrations of the $-\mathrm{C}=\mathrm{C}$ - group (from transformation cis-). A characteristic area includes also vibrations of approximately $1460 \mathrm{~cm}^{-1}$ from bending vibrations of $\mathrm{C}-\mathrm{H}$ groups in groups $\mathrm{CH} 2$ and $\mathrm{CH} 3$ (bending). Vibrations from the range of 890 do $660 \mathrm{~cm}^{-1}$ which present characteristic bending vibrations of $-\mathrm{HC}=\mathrm{CH}$ - groups (conformation cis- outside the plain) and swinging vibrations of the same groups $\left(\delta\left(-\left(\mathrm{CH}_{2}\right)\right.\right.$ nand $-\mathrm{HC}=\mathrm{CH}-$ ( cis -) should also be mentioned (Guillen and Cabo, 1997; Nunes, 2014).

On the other hand, vibrations from the scope of higher wave numbers significant valence vibrations $=\mathrm{C}-\mathrm{H}$ (trans-) with the maximum of approximately $3060 \mathrm{~cm}^{-1}$ from vibrations of triglyceride fractions (with a very low intensity) should be mentioned. On the other hand, for valence vibrations $=\mathrm{C}-\mathrm{H}$ of cis- configuration quite intense vibrations with the maximum at approximately $3006 / 8 \mathrm{~cm}^{-1}$ (fig. 1) are quite characteristic. Then, several vibrations with the maximum at approx. 2952/6, 2921/5 and 2855/2 $\mathrm{cm}^{-1}$ come from valence vibrations - $\mathrm{C}-\mathrm{H}$ respectively in groups $-\mathrm{CH}_{3}, \mathrm{CH}_{2}$ which belong to aliphatic groups in triglycerides (Li et al., 2013).

Moreover, it should be mentioned that in the spectra of the investigated oils from rape and pumpkin (Fig.1) clear differences in the shape of bands from the area of $1775-1675$ $\mathrm{cm}^{-1}$ are visible. For majority of the investigated samples, one may notice slight foundation for the band at $1743 / 4 \mathrm{~cm}^{-1}$ (responsible for vibrations of $\mathrm{C}=\mathrm{O}$ group) on the side of lower wave numbers with explicit maximum at approx. $1709 \mathrm{~cm}^{-1}$, which may be justified by the hydrogen bond between $\mathrm{C}=\mathrm{O} \cdots \mathrm{H}-\mathrm{O}-\mathrm{H}$ in oil samples selected for the research. Simultaneously along with the band at $1709 \mathrm{~cm}^{-1}$ a clear increase of bands intensity at approx. 1360 , $721 \mathrm{~cm}^{-1}$ which we ascribe to valence vibrations in C-O and C-C groups (described above) is visible. The area between $1100-1300 \mathrm{~cm}^{-1}$ corresponds also to valence vibrations of C-O group, but it indicates slight changes in the investigated samples of oils regardless the origin (oils from pumpkin and rape). These bands along with the decrease of affinity of particles comprising them, for formation of hydrogen bond between $\mathrm{C}=\mathrm{O} \cdots \mathrm{H}-\mathrm{O}-\mathrm{H}$ may indicate a slight increase of their intensity.

Changes in spectra correlate well with the changes in the fatty acids profiles presented in Table 1. It should be also mentioned that in the cross section of FTIR spectrum considerably bigger differences are reported in case of oil spectra obtained from rapeseed (all cultivars selected for research). The above changes were also included in Table 1 in detail respectively for samples of oils obtained from rape as well as from pumpkin.

All other bands were ascribed to vibrations of relevant functional groups and collected for comparison in Table 2 . 
Profile of fatty acids...

\section{Conclusion}

The objective of the research was to present a possibility of using spectroscopy in FTIR for analysis of quality and spectral characteristic of rape and pumpkin oil spectra. Research was carried out for three types of pumpkin oils such as: 'Olga', 'Junona' and 'Miranda' and three rape oil types such as: 'Abakus', 'Bellevue', 'Adriana'. The obtained results were referred to the available ones in literature of oil and ester spectra.

1. The content of fatty acids in pumpkin and rape seeds of the analysed cultivars was varied. Linoleic acid (C18:2n6c) prevailed in pumpkin seeds and oleinic acid in rape seeds (C18:1n9c).

2. Fatty acids occurring in the analysed seeds include unsaturated bonds in the carbon chain which may be subject to hydrolysis, autoxidation or polymerization. It may affect the quality of biofuel because indexes important for combustion may be changed. These are: viscosity, cetane number or tendency to coke deposition.

3. With the use of ATR-FTIR spectroscopy a very fast and cheap quality analysis of oils for biofuels or food products can be made.

\section{References}

Achremowicz, K., Szary-Sworst, K. (2005). Wielonienasycone kwasy thuszczowe czynnikiem poprawy stanu zdrowia człowieka. Żywność. Nauka. Technologia. Jakość, 3(44), 23-55.

Abdul, R., Che Man, Y.B., Yusof, F.M. (2014). The use of FTIR spectroscopy and chemometrics for rapid authentication of extra virgin olive oil. JAOCS, Journal of the American Oil Chemists' Society 91.2, 207-213.

Ahmad, J., Yusup, S., Bokhari, A., Kamil, R.N.M. (2014). Study of fuel properties of rubber seed oil based biodiesel. Energy Conversion and Management, 78, 266-275.

Bouzid, O., Navarro, D., Roche, M., Asther, M., Haon, M., Delattre, M., Lorquin, J., Labat, M., Asther, M., Lesage-Meessen, L. (2005). Fungal enzymes as a powerful tool to release simple phenolic compounds from olive oil by-product. Process Biochemistry, 40, 1855-1862.

Bryś, J., Wirkowska, M., Górska, A., Ostrowska-Ligęza, E., Bryś, A., Koczoń, P. (2013). The use of DSC and FT-IR spectroscopy for evaluation of oxidative stability of interesterified fats. Journal of Thermal Analysis and Calorimetry, 1-7, 23.

Ciemniewska-Żytkiewicz, H., Bryś, J., Sujka, K., Koczoń, P. (2015). Assessment of the hazelnuts roasting process by pressure differential scanning calorimetry and MID-FT-IR spectroscopy. Food Analytical Methods, 8(10), 2465-2473.

Dubois, V., Breton, S., Linder, M., Fanni, J., Parmentier, M. (2007). Fatty acid profiles of 80 vegetable oils with regard to their nutritional potential. European Journal of Lipid Science and Technology, 109, 710-732.

Eder, K., Brandsch, C. (2002). The effect of fatty acid composition of rapeseed oil on plasma lipids and oxidative stability of low-density lipoproteins in cholesterol-fed hamsters. European Journal of Lipid Science and Technology, 104, 3-13.

El-Adawy, T.A. Taha, K.M. (2001). Characteristics and composition of different seed oils and flours. Food chemistry, 74, 47-54.

Guillen, M.D., Cabo, N. (1997). Infrared spectroscopy in the study of edible oils and fats. Journal of the Science of Food and Agriculture, 75, 1-11.

Guillen, M.D., Cabo, N. (1997). "Characterization of edible oils and lard by Fourier transform infrared spectroscopy. Relationships between composition and frequency of concrete bands in the fingerprint region. Journal of the American Oil Chemists' Society, 74.10, 1281-1286. 
Gurdeniz, G., Ozen, B. (2009). Detection of adulteration of extra-virgin olive oil by chemometric analysis of mid-infrared spectral data. Food Chemistry, 116, 519-525.

Kapoor R., Huang, Y.-S. (2006). Gamma linolenic acid: an antiinflammatory omega-6 fatty acid. Current pharmaceutical biotechnology, 7, 531-534.

Kim, K.-N., Heo, S.-J., Song, C.B., Lee, J., Heo, M.-S., Yeo, I.-K., Kang, K.A., Hyun, J.W., Jeon, Y.J. (2006). Protective effect of Ecklonia cava enzymatic extracts on hydrogen peroxide-induced cell damage. Process Biochemistry, 41, 2393-2401.

Koczoń, P., Lipińska, E., Czerniawska-Piątkowska, E., Mikuł, M., Bartyzel, B.J. (2016). The change of fatty acids composition of Polish biscuits during storage. Food chemistry, 202, 341-348.

Kolayli, S., Tarhan, O., Kara, M., Aliyazicioglu, Kucuk, R.M. (2011). An investigation of frequently consumed edible oils in Turkey in terms of omega fatty acids. Chemistry of Natural Compounds, $47,347$.

Koutsouki, A., Tegou, E., Badeka, A., Kontakos, S., P. Pomonis Kontominas, M., (2016). In situ and conventional transesterification of rapeseeds for biodiesel production. The effect of direct sonication. Industrial Crops and Products, 84, 399-407.

Latif, S., Anwar, F., Ashraf, M. (2007). Characterization of enzyme-assisted cold-pressed cottonseed oil. Journal of Food Lipids, 14, 424-436.

Lazos, E. S., Tsaknis, J., Bante, M., (1995). Changes in pumpkin seed oil during heating. Grasas y aceites, 46, 233-239.

Mansour, E., Dworschak, E.J., Peredi, A. (1993). Lugasi, Evaluation of pumpkin seed (Cucurbita pepo, Kakai 35) as a new source of protein. Acta Alimentaria-an International Journal of Food Science, 22, 3-14.

Mehrotra, R. (2006). Infrared Spectroscopy, Gas Chromatography/Infrared in Food Analysis. John Wiley \& Sons, Ltd, 2000.

Murkovic, M. Pfannhauser, W. (2000). Stability of pumpkin seed oil. European Journal of Lipid Science and Technology, 102, 607-611.

Nunes Cleiton, A. (2014). Vibrational spectroscopy and chemometrics to assess authenticity, adulteration and intrinsic quality parameters of edible oils and fats. Food Research International, $60,255-261$

Obiedzińska, A., Waszkiewicz-Robak, B. (2012). Oleje tłoczone na zimno jako żywność funkcjonalna. Zywność. Nauka. Technologia. Jakość, 1(80), 27-44.

Parker, T.D., Adams, D., Zhou, K., Harris, M., Yu, L. (2006). Fatty acid composition and oxidative stability of cold-pressed edible seed oils. Journal of Food Science, 68, 1240-1243.

Parry, J., Hao, Z., Luther, M., Su, L., Zhou, K., Yu, L.L. (2006). Characterization of cold-pressed onion, parsley, cardamom, mullein, roasted pumpkin, and milk thistle seed oils. Journal of the American Oil Chemists' Society, 83, 847-854.

Parry, J. Yu, L. (2004). Fatty acid content and antioxidant properties of cold-pressed black raspberry seed oil and meal. Journal of Food Science, 69, 22.

Radović, Jagoš, R., Aeppli, Ch., Nelson, R.K., Jimenez, N., Reddy, Ch.M., Bayona, J.M., Albaigés, J. (2014). Assessment of photochemical processes in marine oil spill fingerprinting. Marine Pollution Bulletin 79.1, 268-277.

Ramadan, M.F. Mörse,1 J.-T. (2003). Oil goldenberry (Physalis peruviana L.). Journal of Agricultural and Food Chemistry, 51, 969-974.

Sabudak, T. (2007). Fatty acid composition of seed and leaf oils of pumpkin, walnut, almond, maize, sunflower and melon. Chemistry of Natural Compounds, 43(4), 465-467.

Safar, M., Bertrand, D., Robert, P., Devaux, M.F., Genot, C. (1994). Characterization of edible oils, butters and margarines by Fourier transform infrared spectroscopy with attenuated total reflectance. Journal of the American Oil Chemists' Society 71.4, 371-377.

Schinas, P., G. Karavalakis, C. Davaris, G. Anastopoulos, D. Karonis Zannikos, F., Stournas, S., Lois, E. (2009). Pumpkin (Cucurbita pepo L.) seed oil as an alternative feedstock for the production of biodiesel in Greece. Biomass and Bioenergy, 33, 44-49. 
Profile of fatty acids...

Soto, C., Concha, J., Zuniga, M. (2008). Antioxidant content of oil and defatted meal obtained from borage seeds by an enzymatic-aided cold pressing process. Process Biochemistry, 43, 696-699.

Standard For Named Vegetable Oils Codex Stan. Codex Alimentarius, 210-(1999).

Sujka, K., Koczoń, P., Ceglińsk, A., Reder, M., Ciemniewska-Żytkiewicz, H. (2017). The Application of FT-IR Spectroscopy for Quality Control of Flours Obtained from Polish Producers. Journal of analytical methods in chemistry, 1-9, 11.

Yang, H., Irudayaraj, J., Paradkar, M.M. (2005). Discriminant analysis of edible oils and fats by FTIR, FT-NIR and FT-Raman spectroscopy. Food Chemistry, 93, 25-32.

Yan-qun, L., De-xin, Kong, Wu, H. (2013). Analysis and evaluation of essential oil components of cinnamon barks using GC-MS and FTIR spectroscopy." Industrial Crops and Products 41, 269-278.

Younis, Y., Ghirmay, S., Al-Shihry, S. (2000). African Cucurbita pepo L.: properties of seed and variability in fatty acid composition of seed oil. Phytochemistry, 54, 71-75.

Verma, P., Sharma, M. (2016). Review of process parameters for biodiesel production from different feedstocks. Renewable and Sustainable Energy Reviews, 62, 1063-1071.

Vlachos, N., Skopelitis, Y., Psaroudaki, M., Konstantinidou, V., Chatzilazarou, A., Tegou, E. (2006) Applications of Fourier transform-infrared spectroscopy to edible oils." Analytica Chimica Acta, $573,459-465$

\section{PROFIL KWASÓW TŁUSZCZOWYCH ORAZ CHARAKTERY- STYKA SPEKTROSKOPOWA WYBRANYCH OLEJÓW POCHODZENIA ROŚLINNEGO TŁOCZONYCH NA ZIMNO}

Streszczenie. Biodiesel staje się coraz bardziej atrakcyjnym materiałem ze względu na swoje właściwości takie jak: biodegradowalność, odnawialność oraz bardzo niską toksyczność produktów powstających z jego spalania. Jakość tego paliwa ma również docelowo zasadnicze znaczenie w jego potencjalnej komercjalizacji. Metody analityczne używane $\mathrm{w}$ badaniach biodiesla są cały czas udoskonalane. Do najpopularniejszych technik analitycznych zaliczyć należy chromatografię oraz metody spektroskopii molekularnej, a wśród nich spektroskopię $\mathrm{w}$ podczerwieni ATR-FTIR. $\mathrm{W}$ prezentowanym artykule przedstawiono wyniki badań wykonanych za pomocą spektroskopii absorpcyjnej w podczerwieni ATR-FTIR wybranych do badań olejów pochodzenia naturalnego, tj. z nasion dyni oraz rzepaku ozimego. We wszystkich próbkach oznaczono także zawartość głównych kwasów thuszczowych.

Słowa kluczowe: nasiona dyni, nasiona rzepaku, oleje roślinne, kwasy thuszczowe, ATR-FTIR 